\title{
Dakwah melalui Konseling Individu
}

\author{
Ahmad Putra ${ }^{1}$ \\ ${ }^{1}$ Interdisciplinary Islamic Studies, UIN Sunan Kalijaga Yogyakarta \\ 1pratamaahmad954@gmail.com
}

$\begin{array}{ccc}\text { First received: } & \text { Revised: } & \text { Final Accepted: } \\ \text { 01 January 2019 } & \text { 02 February 2019 } & \text { 04 March 2019 }\end{array}$

\begin{abstract}
This paper explains about presenting the values of da'wah through individual counseling whose purpose is to provide religious / Islamic nuanced solutions to a variety of problems that exist in human life. The method used by the author in this research is descriptive analysis method, in which the author presents data from several relevant opinions and tested through various sources and then analyzes them, so as to produce a more effective and relatively new alternative in da'wah, namely through individual counseling. Then preaching must be packaged in the right method, which must be actual, factual, and contextual. One approach to convey the message of preaching is through individual counseling activities. Da'wah through individual counseling has several characteristics, namely the formation of communication between counselor and client, oriented toward problem solving efforts, delivery of messages that have been programmed, and the targets and objectives set. In addition, propaganda through individual counseling has several characteristics, namely trying to raise awareness to internalize the values / teachings of Islam in certain circles that are very specific and individual.
\end{abstract}

Keywords: Da'wah, Individual Counselling, Islam

\begin{abstract}
Abstrak
Tulisan ini menjelaskan tentang menghadirkan nilai-nilai dakwah melalui konseling individu yang tujuannya ialah untuk memberikan solusi bernuansa keagamaan//slam terhadap beranekaragam permasalahan yang ada dalam kehidupan manusia. Metode yang penulis pergunakan dalam riset ini adalah metode analisis deskriptif, yang mana penulis memaparkan data dari beberapa pendapat yang relevan dan teruji melalui berbagai sumber kemudian menganalisisnya, sehingga menghasilkan sebuah alternatif yang lebih efektif dan relatif baru dalam dakwah, yaitu melalui konseling individu. Maka dakwah harus dikemas dalam metode yang tepat, yaitu harus aktual, faktual, dan kontekstual. Salah satu pendekatan untuk menyampaikan pesan dakwah tersebut adalah melalui kegiatan konseling individu. Dakwah melalui konseling individu memiliki beberapa karakteristik, yakni terbentuknya komunikasi antara konselor dengan klien, berorientasi pada upaya pemecahan masalah, penyampaian pesan yang sudah terprogram, dan adanya target serta tujuan yang ditetapkan. Selain itu, dakwah melalui konseling individu memiliki beberapa karakteristik yaitu mencoba menumbuhkan kesadaran untuk menginternalisasikan nilainilai/ajaran Islam di kalangan tertentu yang sangat spesifik dan bersifat individual.
\end{abstract}

Kata Kunci: Dakwah, Konseling Individu, Islam

\section{PENDAHULUAN}

Islam merupakan agama yang menjanjikan sebuah keselamatan dalam hidup baik di dunia maupun di akhirat, ajarannya mengantarkan semua manusia kepada arah yang benar, lurus, memberikan kenikmatan yang tanpa batas, serta rahmat bagi semua manusia. Maka, ajaran Islam perlu disampaikan kepada khalayak banyak dan saling mengingatkan akan pentingnya mengetahui kenikmatan yang Islam bawa untuk umatnya (Razak, 1973). 
Islam identik dengan dakwah atau sering kita dengar dengan istilah berdakwah. Berdakwah adalah sebuah kewajiban umat muslim, dengan kata lain bahwa ajaran yang dibawa oleh Islam hendaknya dapat dibagi atau disampaikan kepada semua umat. Dakwah bukan hanya sebatas berceramah dan menyampaikan khutbah didepan mimbar, dakwah memiliki cakupan serta aplikasi yang bermacam-macam. Dakwah bisa berupa lisan, tulisan, seni, ataupun cara lain yang pada dasarnya membawa manusia kepada jalan kebenaran, jalan yang menjadikan seseorang tersebut berada pada posisi yang mencintai agama Allah (Islam). Dengan itu, ajaran yang Islam bawa akan mampu diaplikasikan dalam hidup dan mampu diamalkan dengan sebaik mungkin oleh yang menerima (mad'u) (Arifin, 1993).

Dalam memahmi dakwah dan ajaran Islam, manusia hendaknya tahu bahwa dalam hidup ini bukan hanya menjalani kesibukan serta profesi yang berjalan seperti apa adanya. Akan tetapi, ada tugas yang lebih penting yaitu menjadi pribadi yang bisa berhubungan baik dengan Tuhan semesta alam, berhubungan baik dengan sesama manusia dan alam (Anshari, 1993).

Sesungguhnya Islam hadir dan datang dalam kehidupan manusia bertujuan agar manusia mampu mengalamalkan tata cara hidup yang telah Al-Qur'an jelaskan, semuanya telah terpaparkan dengan baik, maka manusia harus melandasi diri dan cara hidup dengan yang ajaran Islam jelaskan.

Ajaran Islam yang ada dalam AlQur'an bukan hanya sekedar tulisan dan penyampaian begitu saja, namun juga menjelaskan bagaimana menjalani kehidupan yang benar, membentuk kepribadian, membina diri, membentuk keluarga dengan baik dan bagaimana membentuk masyarakat yang berasaskan Islam (Nuh, 2000).

Jelas terlihat bahwa ajaran Islam berusaha membawa manusia dapat memahami bahwa konsep amar makruf nahi mungkar sebagai pokok penting dalam menjalani kehidupan ini (Al-Wa'i, 1989). Kehidupan masyarakat yang saat ini begitu kompleks dan beraneka ragam seiring dengan majunya pola kehidupan yang dibawa oleh perkembangan zaman.

Dakwah yang dibawa atau diberikan kepada penerima, tentunya harus disampaikan dengan tata cara yang benar. Dalam artian, orang yang menyampaikan hendaknya benar benar memahami cara berdakwah yang sesuai dengan Islam, sehingga penerima dakwah (mad'u) dapat menerima dakwah serta ajakan dengan lapang dada (Nuh, 2000).

Jangan sampai mad'u menerima dakwah dengan rasa terpaksa karena itu akan menjadikan dirinya menolak ajakan yang diberikan da'i. maka, da'i (pemberi dakwah) benar-benar memahami sebuah cara atau strategi dalam memberikan ajakan atau sebuah pengajaran kepada banyak orang, agar diterima dengan senang hati.

Pemberi dakwah yang memberikan sebuah pengajaran hendak mengoptimalkan sebaik mungkin sesuatu yang diberikan kepada penerima, karena pemberi dakwah dapat dianalogikan seperti seorang dokter yang memberikan resep obat kepada pasien, sehingga resep yang diberikan tersebut mampu menghilangkan rasa sakit yang dirasakan pasien. Begitulah dengan seorang pemberi dakwah, ia memberikan ajakan dan bimbingan dengan tujuan orang yang menerima dakwah mampu menemukan 
jalan keluar dari sebuah permasalahan yang ia alami.

Oleh karena itu, konseling individu hadir dan menjadi salah satu solusi dalam membantu seseorang yang mengalami sebuah permasalahan dengan maksud membantu agar dapat menemukan solusi dalam menyelesaikannya. Dengan pertemuan secara langsung antara pembimbing dengan yang dibimbing, menjadikan sebuah momen dalam menerapkan nilai-nilai dakwah kepada penerima dakwah agar ia mampu menghadapi permasalahan yang dialami.

\section{METODE PENELITIAN}

Metode yang penulis gunakan dalam riset ini adalah metode analisis deskriptif, dimana penulis memaparkan data dari beberapa pendapat yang relevan dari berbagai sumber kemudian menganalisisnya, sehingga menghasilkan sebuah alternatif yang lebih efektif dan relatif baru dalam dakwah, yaitu melalui konseling individu. Maka dakwah harus dikemas dalam metode yang tepat, yaitu aktual, faktual, dan kontekstual. Aktual dalam arti memecahkan masalah kekinian dalam masyarakat, factual dalam arti nyata (tidak sekedar teori), serta kontekstual dalam arti relevan dan menyangkut problem yang dihadapi masyarakat.

\section{PEMBAHASAN}

\section{Mengenal Makna Dakwah}

Dakwah menurut etimologi berasal dari kata bahasa Arab yaitu da'a-yad'uda'watan yang berarti mengajak, menyeru, dan memanggil (Amin, 2006). Dakwah juga berarti mendorong ataupun memohon (An-Nabiry, 2008). Pada hakikatnya, dakwah upaya untuk menumbuhkan kecenderungan dan ketertarikan. Menyeru seseorang pada agama Islam dan maknanya adalah setiap kita berupaya untuk menumbuhkan kecenderungan dan ketertarikan pada apa yang kita serukan, yaitu Islam. Dakwah tidak hanya terbatas pada aktivitas lisan saja, tetapi mencakup seluruh aktivitas lisan atau perbuatan yang ditujukan dalam rangka menumbuhkan kecenderungan dan ketertarikan pada Islam (Mahmud, 2006).

Muhammad Fuad Abdul Baqi mengatakan, bahwa dalam Al-Qur'an, kata dakwah dan kata-kata yang terbentuk darinya disebutkan tidak kurang dari 213 kali (Baqi, tt). Suatu sebutan yang tidak sedikit berkaitan dengan perintah ajakan kepada ajaran Islam. Dasar-dasar dakwah disebutkan dalam Al-Qur'an antara lain :

"Serulah manusia kepada jalan Tuhanmu dengan hikmah dan pelajaran yang baik dan bantahlah mereka dengan cara yang baik. Sesungguhnya Tuhanmu Dialah yang lebih mengetahui tentang siapa yang tersesat dari jalannya dan dialah yang lebih mengetahui orang-orang yang mendapat petunjuk" (QS. An-Nahl : 125).

"Hendaklah ada di antara kamu segolongan umat yang menyeru kepada kewajiban, menyuruh kepada yang makruf dan mencegah yang mungkar, merekalah orang-orang yang beruntung" QS. Ali-Imran : 104.

Dasar dakwah dalam hadits dijelaskan:

"Barangsiapa di antara kamu melihat kemungkaran, maka hendaklah ia mengubahnya dengan tangannya, apabila ia tidak mampu maka dengan lisannya, apabila tidak mampu maka dengan hatinya dan yang demikian itu 
adalah selemah-lemah iman" (HR. Muslim) (Imam Nawawi, tt).

Dakwah menyeru kepada mereka yang beragama Islam dalam kategori kedua atau turunan atau menyeru Islam kepada mereka yang belum beragama Islam. Di dalam dakwah, Islam disebutnya Alkhair yang berarti sesuatu yang baik. Berarti dakwah tidak langsung menyebut Islam, tetapi dimulai dengan mempertujukkan kebaikan-kebaikan, sedangkan bila telah mereka kagumi segala nilai-nilai baiknya, barulah terungkap hakikat Islamnya dan karena itu mereka akan memasuki dan melaksanakan Islam dengan sebaik-baiknya (Muttaqien, 1982). Dakwah itu ibarat meminta tolong pada orang lain, memerlukan tata sopan santun yang tepat dan benar, sehingga orang yang disuruh bukan hanya tidak keberatan tetapi ia mendapatkan kepuasan disuruh mengerjakan sesuatu.

Secara terminologi ada beberapa ahli yang menjelaskan terkait apa itu dakwah, diantaranya :

a. Menurut Syaikh Ali Mahfudz, dakwah merupakan memotivasi manusia untuk berbuat kebajukan, mengikuti petunjuk, memerintahkan kebaikan dan mencegah kemungkaran, agar mereka memperoleh kebahagiaan di dunia dan akhirat (Syaikh Ali Mahfudz, tt).

b. Menurut M. Natsir, dakwah merupakan usaha-usaha menyerukan dan menyampaikan kepada perorangan manusia dan seluruh umat manusia konsepsi Islam tentang pandangan dan tujuan hidup manusia di dunia ini, dan yang meliputi amar ma'ruf nahi munkar dengan berbagai macam cara dan media yang diperbolehkan akhlak dan membimbing pengalamannya dalam perikehidupan bermasyarakat dan perikehidupan bernegara (Mulkhan, 1996).

c. Menurut Yusuf Qardhawi, dakwah adalah ajakan kepada agama Allah, mengikuti petunjuk-Nya, mencari keputusan hukm kepada metodeNya di bumi, mengesakan-Nya dalam beribadah, meminta pertolongan dan ketaatan, membenarkan diri semua yang dibenarkan Allah (An-Nabiry, 2008).

d. Menurut Abu Bakar Aceh, dakwah merupakan dari kata $d a^{\prime} a$, berarti perintah mengadakan seruan kepada semua manusia untuk kembali dan hidup sepanjang ajaran Allah yang benar, dilakukan dengan penuh kebijaksanaan dan nasihat yang baik. Kata-kata ini mempunyai arti yang luas sekali, tetapi tidak keluar dari pada tujuan mengajak manusia hidup sepanjang agama dan hukum Allah (Aceh, 1986).

e. Menurut A. Hasjmy, dakwah merupakan mengajak orang lain untuk meyakini dan mengamalkan akidah dan syariah islam yang terlebih dahulu diyakini dan diamalkan oleh pendakwah itu sendiri (Hasjmy, 1984).

f. Menurut Toha Yahya Omar, dakwah itu ialah mengajak manusia dengan cara bijaksana kepada jalan yang benar sesuai dengan perintah Tuhan, yaitu keselamatan dan kebahagiaan mereka di dunia dan akhirat (Yahya, 1984,).

g. Menurut Endang Saifuddin Anshari, dakwah adalah segala aktivitas dan usaha yang mengubah satu situasi kepada situasi yang 
lebih baik menurut ajaran Islam (Anshari, 1982).

h. Menurut Amrullah Ahmad, dakwah adalah aktualisasi iman yang dimanifestasikan dalam suatu system kegiatan manusia beriman dalam bidang suatu system kegiatan manusia beriman dalam bidang kemasyarakatan yang dilaksanakan secara teratur, mempengaruhi cara merasa, berpikir, bersikap dan bertindak (Ahmad, 1983).

Dakwah juga bisa diartikan sebagai proses penyampaian ajaran agama Islam kepada umat manusia. Sebagai suatu proses, dakwah tidak hanya merupakan usaha penyampaian saja, tetapi merupakan usaha untuk mengubah way of thinking, way of feeling dan way of life manusia sebagai sasaran dakwah ke arah kualitas kehidupan yang lebih baik. Dakwah dapat dikatakan sebagai aktualisasi nilai-nilai Islam yang diterjemahkan kedalam ajaranajaran Islam bagi upaya mewujudkan kebahagiaan hidup manusia di dunia ini. dengan demikian, dakwah merupakan aktualisasi fungsi kerisalahan dan sebagai manifestasi rahmatan lil 'alamin, dikarenakan bahwa agama Islam mengandung nilai-nilai humanis teosentris yang universal bagi semua umat manusia. Maka dengan itu, setiap individu muslim berkewajiban untuk menyampaikan dakwah Islam kepada orang lain menurut kemampuan masing-masing.

\section{Proses Pengaplikasian Dakwah}

Dakwah merupakan sebuah tugas mulia yang dilakukan manusia, dengan mengajak kepada sesuatu kepada arah kebenaran dan kebaikan, akan mengahsilkan manusia yang hidup dalam keharmonisan. Sudah patut dan pantaslah bila prinsip dari dakwah menjadi sebuah hal yang perlu ditanamkan pada setiap manusia. Secara umum, dakwah Islam dapat dikategorikan kepada tiga bentuk dan dengan tiga bentuk inilah menjadi sebuah cara dalam mengaplikasikan dakwah dalam kehidupan, yaitu :

a. Dakwah bil lisan

Dakwah bil lisan merupakan dakwah yang dilakukan melalui lisan, yang dilakukan antara lain dengan ceramah-ceramah, khutbah, diskusi, nasihat dan lain-lain. metode ceramah ini tampaknya sudah sering dilakukan oleh para juru dakwah, baik ceramah di majelis taklim, khutbah jumat di masjid-masjid atau pengajianpengajian. Dari aspek jumlah barangkali dakwah melalui lisan (ceramah dan yang lainnya) ini sudah cukup banyak dilakukan oleh para juru dakwah di tengah-tengah masyarakat.

\section{b. Dakwah bil hal}

Dakwah bil hal merupakan dakwah dengan perbuatan nyata di mana aktivitas dakwah dilakukan dengan melalui keteladanan dan tindakan amal nyata. Misalnya dengan tindakan amal karya nyata yang dari karya nyata tersebut hasilnya bisa dirasakan secara konkret oleh masyarakat sebagai objek dakwah. Dakwah bil hal dilakukan oleh Rasulullah, terbukti bahwa ketika pertama kali tiba di Madinah yang dilakukan Nabi ialah membangun Masjid Quba, mempersatukan kaum Anhar dan Muhajirin. Kedua hal ini ialah dakwah nyata yang dilakukan oleh Nabi yang bisa dikatakan sebagai dakwah bil hal.

Dakwah bil hal sekarang ini bisa dilakukan pada sebuah karya yang nyata sebagai sebuah solusi kebutuhan banyak orang, misalnya membangun 
sekolah Islam, membangun perguruan atau kampus Islam, mendirikan pesantren, membangun rumah sakit, puskesmas dan kebutuhan yang dibutuhkan banyak orang.

c. Dakwah bil qalam

Dakwah bil qalam ialah dakwah yang dilakukan melalui tulisan, dengan keahlian menulis di surat kabar, majalah, buku, maupun internet. Jangkauan yang dapat dicapai oleh dakwah bil qalam ini lebih luas dari pada melalui media lisan, demikian pula metode yang digunakan tidak membutuhkan waktu secara khusus untuk kegiatannya. Kapan saja dan dimana saja mad"u atau objek dakwah dapat menikmati sajian dakwah bil qalam ini.

Dalam dakwah bil qalam ini diperlukan kepandaian yan khusus dalam hal menulis, yang kemudian disebarluaskan melalui media cetak. Bentuk tulisan dakwah bil qalam antara lain dapat berbentuk artikel keislaman, Tanya jawab hukum Islam, rubric dakwah, rubric pendidikan agama, kolom keislaman, cerita religious, cerpen religious, puisi yang bernuansa agama, publikasi khutbah, faplet keislaman, buku-buku dan lain sebagainya (Amin, 2006).

\section{Konseling Individu sebagai Upaya Mengembangkan Dakwah}

Salah satu layanan yang dapat dilaksanakan konselor adalah layanan konseling individu. Prayitno \& Amti menjelaskan bahwa konseling merupakan proses pemberian bantuan melalui wawancara konseling oleh seorang ahli (konselor) kepada individu yang sedang menjalani sesuatu masalah (konseli) yang bermuara pada teratasinya masalah yang dihadapi oleh konseli (Prayitno \& Amti, 2004).

Layanan konseling perorangan atau individu yaitu layanan BK yang memungkinkan peserta didik mendapatkan layanan langsung tatap muka (secara perorangan) dengan guru pembimbing dalam rangka pembahasan dan pengentasan masalah pribadi yang di deritanya. Layanan yang membantu peserta didik dalam mengentaskan masalah pribadinya (Febriani, 2011).

Pada prinsipnya, konseling adalah suatu proses pemberian bantuan yang dilakukan melalui wawancara konseling oleh orang yang ahli (guru pembimbing atau konselor) kepada individu yang sedang mengalami suatu masalah, yang bermuara pada teratasinya masalah yang dihadapi klien (Prayitno \& Amti, 2004).

Konseling individu merupakan layanan konseling yang diselenggarakan oleh seorang konselor terhadap seorang klien dalam rangka pengentasan masalah (Prayitno, 2004). Lalu, konseling individu juga berarti layanan yang ada dalam bimbingan konseling yang dilakukan secara tatat muka yakni antar konselor dengan konseli. Dengan demikian, konseling individu adalah pertemuan konselor dengan konseli secara individual, memberikan bantuan untuk mengembangkan pribadi klien dan siap menjalani masalah yang bisa datang kapan saja bagi dirinya (Willis, 2004).

Menurut Hansen kegiatan layanan konseling individu secara inti memiliki tujuan "assists individual in learning about themselves, their environment, although the individual experience problems............, assists an individual with the decision making process in educational, vocational matters as 
well as resolving interpersonal concerns" (Hansen, 1977).

Adapun tujuan lebih rincinya adalah to tach problem solving procedurees to client with the data that already exist, change the client behaviors, change means giving up dearconfortable habits, cherish values or even painful feeling (Brammers, 1982).

Gibson \& Mitchel mendefinisikan konseling individu sebagai hubungan yang berupa bantuan satu-satu yang berfokus kepada pertumbuhan dan penyesuaian pribadi dan memenuhi kebutuhan akan penyelesaian problem dan kebutuhan pengambilan keputusan (Gibson \& Mitchel, 2011). Ia juga menambahkan bahwa program konseling individu adalah program inti dari keseluruhan layanan bimbingan dan konseling.

Astuti menjelaskan bahwa konseling individu adalah layanan konseling yang memungkinkan individu mendapatkan layanan langsung tatap muka (secara perorangan) untuk mengentaskan permasalahan pribadi yang dihadapi dan perkembangan dirinya (Astuti, 2015).

Dalam pelaksanaan konseling individu, terdapat tiga metode yang bisa digunakan yaitu konseling direktif, konseling non direktif, dan konseling eklektif.

\section{a. Konseling Direktif}

Dalam prosesnya, yang aktif atau paling berperan adalah konselor. Dalam praktiknya konseor berusaha mengarahkan klien sesuai dengan masalahnya. Selain itu, konselor juga memberikan saran, anjuran, dan nasihat kepada klien. Praktik konseling yang dilakukan oleh para penganut teori behavioral counseling umumnya menerapkan cara-cara diatas dalam konselingnya. Karena praktik yang demikian, konseling ini juga dikenal dengan konseling yang berpusat pada konselor (Tohirin, 2011).

Praktik konseling dalam dunia Islam dimana para Nabi khususnya Nabi Muhammad umumnya menerapkan cara-cara proses konseling direktif yaitu memberikan saran-saran, anjuran dan nasihat kepada klien. Nabi dan Rasul bisa bisa disebut konselor apabila melihat tugas dan fungsinya sebagai pembimbing umat kea rah jalan yang benar. Praktik konseling direktif mendapat kritik terutama dari para penganut paham bahwa tujuan utama dalam konseling adalah kemandirian klien (siswa). Apabila klien masih dinasihati dan diarahkan berarti belum mandiri, begitupun sebaliknya sehingga tujuan utama konseling belum tercapai.

b. Konseling Non Direktif

Konseling non direktif atau konseling yang berpusat pada siswa muncul akibat kritik terhadap konseling direktif (konseling berpusat pada konselor). Konseling non direktif dikembangkan berdasarkan teori client centered (konseling yang berpusat pada klien atau siswa)

c. Konseling Eklektif

Konseling eklektik adalah gabungan dari metode konseling direktif dengan non direktif. Penerapan dalam metode eklektif dilakukan pada keadaan tertentu. Konselor menasehati dan mengarahkan klien (siswa) sesuai dengan masalahnya dan dalam keadaan yang lain konselor memberikan kebebasan kepada klien (siswa) untuk berbicara, sedangkan konselor mengarahkannya saja (Tohirin, 2007). 
Dengan kata lain, agar konseling berhasil secara efektif dan efisien, tentu harus melihat siapa siswa (klien) yang akan dibantu ata dibimbing dan melihat situasi konseling. Apabila terhadap siswa tertentu tidak bisa diterapkan metode direktif, maka mungkin bisa diterapkan metode non direktif begitu juga sebaliknya. Atau apabila mungkin adalah dengan cara mengabungkan kedua metode diatas. Penggabungan kedua metode konseling diatas disebut metode eklektif.

\section{Fungsi dan Tujuan Konseling Individu}

Adapun fungsi konseling Individu, diantaranya :

a. Fungsi Pemahaman, yaitu fungsi pelayanan konseling yang menghasilkan pemahaman tentang sesuatu oleh pihak-pihak tertentu sesuai dengan kepentingan pengembangan individu, seperti: pemahaman tentang diri, lingkungan terbatas (keluarga, sekolah) dan lingkungan yang lebih luas (dunia pendidikan, kerja, budaya, agama, dan adat istiadat).

b. Fungsi Pengentasan, yaitu fungsi konseling yang menghasilkan terentasinya berbagai permasalahan yang dialami individu (Saerozi, 2015).

c. Fungsi Pengembangan dan Pemeliharaan, pengembangan dan pemeliharaan potensi konseli dan berbagai unsur positif yang ada pada dirinya merupakan latar belakang pemahaman dan pengentasan masalah konseli dapat dicapai.

d. Fungsi Pencegahan, fungsi ini membantu individu agar dapat berupaya aktif untuk melakukan pencegahan sebelum mengalami masalah-masalah kejiwaan karena kurangnya perhatian. Upaya preventif meliputi pengembangan strategistrategi dan programprogram yang dapat digunakan untuk mencoba mengantisipasi dan mengelakkan resiko-resiko hidup yang tidak perlu terjadi (Rahim, 2001).

e. Fungsi Advokasi, masalah yang dialami konseli menyangkut dilanggarnya hak-hak konseli sehingga konseli teraniaya dalam kadar tertentu, layanan konseling individu dapat menangani sasaran yang bersifat advokasi (pembelaan).

Sedangkan tujuan konseling individu, diantaranya :

a. Membangun, menjaga, dan memelihara kesehatan mentalnya. Maksudnya, konselor atau guru pembimbing melalui layanan konseling individu berupaya membantu klien (siswa) membangun, menjaga, memelihara, dan memotivasi untuk mendapatkan mental yang sehat, karena dengan mental yang sehat klien akan memiliki integrasi, penyesuaian diri, dan identifikasi positif kepada orang lain. Berarti dalam proses konseling itu klien akan membelajarkan diri menerima tanggung jawab, mandiri, dan mencapai tingkah laku yang integratif. Di samping itu, klien mendapatkan pemenuhan kebutuhan taraf psikososial sampai ke tataran kehidupan ruhanispiritual. Kebutuhan dimaksud, menurut Winkel, antara lain: 
1. Nilai-nilai keteraturan dalam hidup serta pemahaman dan kepastian tentang prediksi apa yang akan terjadi di masa datang.

2. Keyakinan memiliki kepercayaan diri untuk mengatasi setiap persoalan kehidupannya, dengan begitu akan mucul perasaan aman dalam dirinya.

3. Pengakuan diri oleh orang lain sebagai pribadi yang berharga.

4. Kemampuan memberi dan menerima rasa kasih sayang dari diri dan orang lain.

5. Rasa harga diri, yang sangat erat dengan kebutuhan keyakinan atas kemampuan diri dalam mengatasi segala tantangan hidup serta kebutuhan diterima baik oleh orang lain sehingga ia merasa memiliki harga diri di mata orang lain.

6. Pegangan spiritual yang dapat memberikan arah dan makna pada kehidupan klien serta menjadi sumber harapan jiwa dan menjadi benteng serta kekuatan batin saat berada di tengah-tengah kehidupan yang dipenuhi gelombang pasang surut. Ia menjadi sinar terang dalam menapaki kehidupan dan meraih kebahagiaan dunia dan akhirat.

7. Rasa sukses, yaitu kebutuhan untuk sukses meraih prestasi hidup dengan semangat mengembangkan seluruh potensinya.

8. Menemukan sumber-sumber kepuasan, kegembiraan, kebahagiaan hidup yang baru mengacu pada kebahagiaan spiritual, ruhaninya (Winkel, 2004).

b. Membangun kemampuan siswa membuat dan mengambil keputusan yang lebih tepat. Maksudnya bahwa kegiatan layanan konseling individual membelajarkan klien untuk berkemampuan mengambil keputusan secara cepat dan tepat pada saat-saat yang emergency (genting), serta berkemampuan dalam memprediksi konsekuensi logis yang mungkin timbul berkenaan dengan seluruh pengorbanan pribadinya, tenaga, waktu, biaya dan sebagainya. Dalam hal inilah guru dan pembimbing mempunyai peran besar dalam membantu klien/siswa mencapai keberhasilan studi dan hidupnya.

c. Membangun keefektivan pribadi klien (siswa). Konseling harus menggali dan menyeleksi tujuantujuan dengan tingkat kepuasan yang tinggi seiring dengan keterbatasan potensi dan lingkungan yang mengitarinya. Efektivitas pribadi tersebut, meliputi:

1. Pribadi klien yang selaras antara kemampuan diri dengan cita cita, waktu, tenaga serta siap mengambil tanggung jawab ekonomi, fisik maupun psikologis.

2. Pribadi yang berkemampuan mengenal, merumuskan, dan memecahkan masalahmasalahnya.

3. Tampilan klien yang relatif ajeg (konsisten) dalam menjalani situasi khusus peranannya. 
4. Memiliki kemampuan berfikir secara kreatif, produktif, dan murni.

5. Mampu mengontrol dorongandorongan dan merespons secara tepat terhadap gejala frustrasi, konflik batin dalam diri.

d. Mengubah perilaku negatif menjadi positif. Carl Rogers sebagaimana dikutip Andi Mappeare menyatakan bahwa layanan konseling individu pada prinsipnya berupaya "change in personality organization and structure, change behavior, both of which are relative permanent" (Mappeare, 2002) .Pengubahan tersebut lebih mengacu pada perilaku salah suai menjadi perilaku yang lebih tepat. Cara yang dilakukan adalah dengan cara menyadarkan klien atas sikap dan perilakunya yang malasuai tersebut untuk diubah dan diperbaiki. Sekali lagi, klien memahami dan menyadari bahwa sikap dan perilaku lamanya itu mesti dipahami bahwa tidak layak dilakukan dan mesti diubah menuju kondisi yang lebih baik dan tepat. Manfaat tersebut hendaknya dapat dipahami dan diukur sesuai dengan perkembangan dan rumusan-rumusan perubahan perilaku klien yang menggejala sehingga akan memiliki ketajaman analisis hasil yang dicapai.

e. Membelajarkan diri klien untuk mencegah munculnya masalah. Upaya tersebut mencakup mencegah jangan sampai klien mengalami masalah lagi di kemudian hari. Jangan sampai masalah yang dihadapi semakin tambah berat beban mentalnya dan berkepanjangan. Jangan sampai masalah tersebut berakibat lebih buruk dan mengganggu jiwanya secara permanen (Latipun, 2001). Hal ini berarti juga menuntut konselor untuk membelajarkan klien sehingga memiliki kemampuan mengatasi masalah terkait dengan hubungan sosialnya. Kemampuan tersebut mencakup kemampuan berkomunikasi, menerima dan menyampaikan pendapat secara logis, efektif, dan produktif, kemampuan bertingkah laku, berhubungan sosial di rumah, sekolah, dan di masyarakat dengan menjunjung tinggi tata krama, norma, nilai agama, adat-istiadat yang berlaku, kemampuan membangun hubungan dengan teman sebaya, memahami dan melaksanakan disiplin dan taat pada peraturan sekolah dan kemampuan memahami, mengenali, dan mengamalkan hidup yang sehat (Prayitno, 1997).

f. Membantu membangun kualitas belajar siswa. Upaya ini dapat berwujud membangun motivasi dan tujuan belajar siswa, sikap dan kebiasaan belajar yang baik, menerampilkan siswa dalam memilih strategi belajarnya, berdisiplin belajar serta berlatih belajar secara kontinu, memilih strategi penguasaan materi ajar di sekolah, pemanfaatan kondisi fisik, sosial, budaya di sekolah dan lingkungan masyarakat sekitar, dan membangun orientasi studi lanjut (Prayitno, 1997).

g. Membantu mengubah cara pandang klien terhadap masalah. Ketika klien mengubah makna dari situasi problematis dengan mengubah konsepnya, situasi itu sendiri akan dialami secara 
berbeda. Sekali klien berhasil mengalaminya secara berbeda, situasi itu tidak lagi dirasakan problematis. Satu situasi apapun, tidak akan berubah selama klien tidak mengubah cara pandangnya terhadap masalah tersebut. Oleh karena itulah, melalui pelibatan layanan konseling individu, klien diajak untuk belajar mengubah persepsi dalam memandang masalah yang sedang dialaminya secara lebih rasional, dengan menunjukkan bahwa masalah yang dirasakannya menjadi berat sebagai akibat dari persepsinya yang tidak rasional dan tidak logis. Maka dengan cara membiasakan diri klien memecahkan masalah secara rasional. Hasilnya, semakin hari klien memandang bahwa kejadian atau masalah apapun bila dipandang secara logis akan mudah diterima sebagai realitas yang wajar walaupun realitas itu sangat pahit adanya. Tujuan umum layanan konseling individu adalah terentaskannya masalah yang dialami konseli. Apabila masalah konseli itu dicirikan antara lain: sesuatu yang tidak disukai adanya, sesuatu yang ingin dihilangkan, sesuatu yang dapat menghambat atau menimbulkan kerugian, maka upaya pengentasan masalah konseli melalui konseling individu akan mengurangi intensitasi ketidaksukaan atas keberadaan sesuatu yang dimaksud. Dengan layanan konseling individu beban konseli diringankan, kemampuan konseli ditingkatkan dan potensi konseli dikembangkan (Panitia Sertifikasi Guru Rayon 39, 2010).

\section{Dakwah dalam Konseling Individu}

Dakwah yang terlintas dalam benak kita tentunya lebih kepada sebuah ajakan dan sebuah usaha membawa seseorang kepada jalan kebenaran serta perubahan pada dirinya. Dakwah memiliki makna yang luas dan mempunyai kajian yang tidak bisa hanya sebatas sebuah penyampaian ceramah yang segelintir orang bayangkan, namun segala bentuk ajakan serta upaya seseorang kepada jalan kebenaran itu merupakan sebuah dakwah yang sebenarnya, begitupun dengan konseling.

Metode konseling merupakan landasan yang memberikan dan mengarahkan, karena konseling dapat diartikan sebagai suatu proses hubungan seorang dengan seorang dimana yang seorang dibantu dengan seorang lainnya untuk meningkatkan pengertian dan kemampuannya dalam menghadapi masalahnya. Metode konseling merupakan wawancara secara individual dan tatap muka antara konselor sebagai da'i dan klien sebagai mad'u untuk memecahkan masalah yang dihadapinya.

Seseorang yang merasa kurang percaya diri, merasa kurang puas, kurang bermakna, merasa dikucilkan lingkungan, sedang ada konflik dengan teman dekat dan masalahmasalah lainnya, ia bisa datang ke konselor. Konselor sebagai da'I akan membantu mencari pemecahan masalahnya. Dalam pemecahan masalah ada beberapa tahapan yang dilalui masingmasing tahapan ini, dilalui bersama antara da'i dan mad'u.Untuk mencapai tujuan perlu waktu yang relatif lama tergantung dari jenis masalah.

Sebagaimana terdapat pada Q.S AnNahl (16) ayat 125, salah satu metode dakwah yang dilakukan yaitu metode bi al- 
hikmah. Hikmah yang dimaksud di sini adalah hikmah yang harus dimiliki para da'I berupa ilmu dan nasihat atau sesuatu yang dapat memotivasi orang lain kepada kebaikan dan memalingkan mereka dari kejahatan (Pimay, 2006)

Begitupun dengan konseling, konseling pada dasarnya adalah sebuah wadah untuk membantu klien atau seseorang yang tengah mengalami sebuah permasalahan, di momen itulah seorang konselor membawa klien kepada jalan yang nantinya klien sendiri yang menemukan solusi dari permasalahan yang ia alami tersebut. Karena sejatinya, konseling yang terlaksana antara kosnelor dengan klien ialah sebuah perubahan yang sangat diharapkan oleh konselor, sehingga klien menemukan kenyamanannya serta mampu mandiri menjalani berbagai aktivitas yang ia lakukan.

Salah satu teknik yang ada dalam bimbingan konseling ialah konseling individu. Kita mengenal bimbingan konseling memiliki dua pembagian, ada bimbingan konseling yang berada dibawah ranah umum seperti yang ada di sekolahsekolah dan ada juga yang berada pada ranah keagamaan, seperti konseling islam dan sebagainya. Akan tetapi, kedua bentuk tersebut tetaplah menjadi bagian dari bimbingan dan konseling yang sama-sama berfungsi dalam membantu seseorang klien dalam menghadapi permasalahan yang dialami. Begitupun ketika kita melihat tujuan yang ingin dicapai dari konseling individu da konseling Islam, keduanya sama-sama bertujuan yang sifatnya membantu klien yang bersangkutan.

Makna konseling Islam yang di ungkapkan oleh Tohari Musnamar adalah proses pemberian bantuan terhadap individu agar menyadari kembali eksistensinya sebagai makhluk Allah yang seharusnya hidup selaras dengan ketentuan dan petunjuk Allah sehingga dapat mencapai kebahagian hidup di dunia dan di akhirat. Menurut Syaiful Akhiar Lubis menyebutkan konseling Islam adalah proses konseling yang bertujuan atau berorientasi pada tujuan pendidikan Islam, membangun kehidupan sakinah, kehidupan yang tidak hanya sekedar mencapai kemakmuran tetapi juga mencapai ketentrama hidup spiritual (Musnamar, 1992).

Sedangkan menurut Sutoyo konseling Islam adalah upaya membantu individu belajar mengembangkan fitrah dan atau kembali kepada fitrah, dengan cara memberdayakan (enpowering) iman, akal dan kemauan yang dikaruniakan Allah SWT, kepadanya untuk mempelajari tuntunan Allah dan Rosul-Nya, agar fitrah yang ada pada individu itu berkembang dengan benar dan kokoh sesuai dengan tuntunan Allah.

Metode konseling dalam dakwah diperlukan mengingat banyaknya masalah yang terkait dengan keimanan dan pengalaman keagamaan yang tidak bisa diselesaikan dengan metode ceramah ataupun diskusi. Tidak sedikit masalah yang harus diselesaikan secara khusus, secara individual melalui tatap muka antara da'i dan mad'u (Arifuddin, 2015)

Dalam meraih dan mendapatkan keberhasilan dalam pengembangan dakwah, maka perlu diperhatikan sebagai berikut :

a. Diperlukan dakwah dan strategi yang jitu, sehingga perubahan yang ada akibat dakwah tidak terjadi secara frontal, tetapi bertahap sesuai fitrah manusia. 
b. Dakwah Islam seharusnya dilakukan dengan menyejukkan, mencari titik persamaan bukan perbedaan, meringankan bukan mempersulit, menggembirakan bukan menakut-nakuti (Suparta \& Hefni, 2003).

Dengan mengetahui bagaimana permasalahan yang dimiliki individu maka perlu adanya pelaksanaan layanan konseling individu sebagai pendekatan yang tepat dalam dakwah untuk memecahkan suatu permasalahan yang sedang dialami individu. Aktivitas dakwah dilakukan dengan mengajak, mendorong, menyeru tanpa tekanan atau provokasi serta bukan dengan bujukan (Ma'arif, 2010). Hal ini semakin diperkuat oleh Pohan, R. A., \& Ramadhani, E. (2018) bahwa konseling di Fakultas Dakwah PTKIN rumpun ilmunya adalah ilmu Dakwah. Hal ini dapat ditafsirkan melalui PMA No. 33 tahun 2016 maupun kompetensi lulusannya menjadi konselor islami maupun penyuluh agama Islam.

Dengan begitu konselor dapat memberikan arahan dengan kepada individu sesuai apa yang sedang di alaminya dan mengajak kepada kebaikan, maka konselor sama artinya menjalankan proses dakwah kepada orang lain. Dari uraian ini berarti layanan konseling individu berkaitan erat dengan dakwah karena antara dakwah dan layanan konseling individu ini memiliki arah dan tujuan yang sama yaitu mengarahkan kepada kebaikan untuk membimbing dalam menyelesaikan suatu masalah.

Dalam teknik ini pemberian bantuan dilakukan dengan konseling individual yaitu dengan hubungan yang bersifat face to face relationship (hubungan empat mata) yang dilaksanakan dengan wawancara antara konselor dan konseli. Masalah yang dipecahkan melalui teknik konseling ini ialah masalah-masalah yang sifatnya pribadi. Dari beberapa model layanan bimbingan, sebagai tenaga bimbingan sudah seharusnya memiliki pengetahuan dan pemahaman psikologi yang cukup mendalam serta memiliki fleksibilitas yang tinggi dan kesabaran yang besar, sebagaimana Allah berfirman dalam QS. An-Nahl (16): 125 yang berbunyi :

"Serulah (manusia) kepada jalan Tuhanmu dengan hikmah dan pelajaran yang baik dan bantahlah mereka dengan cara yang baik. Sesungguhnya Tuhanmu Dialah yang lebih mengetahui tentang siapa yang tersesat dari jalan-Nya dan Dialah lebih mengetahui orangorang yang mendapat petunjuk" (Departemen Agama RI, 2004 ).

Dapat dipahami bahwa melalui konseling individu, dakwah bisa disalurkan kepada klien, keadaan klien yang tengah tidak stabil menjadikan sebuah peluang bagi konselor dalam memberikan sebuah perubahan pada diri klien serta mengharapkan sebuah perubahan kepada yang lebih baik.

\section{KESIMPULAN}

Berdasarkan uraian di atas, dapat dipahami bahwa berdakwah adalah kewajiban semua umat Muslim. Dengan mengajak, menasehati dan membawa seseorang kepada jalan kebenaran maka akan tercipta kehidupan yang benar sehingga sesuai dengan ajaran Islam. Pemberi dakwah dengan orang yang menerima dakwah secara tidak langsung telah seperti gambaran yang terjalin antara konselor dengan klien dalam proses bimbingan dan konseling. Sehingga, konseling individu hadir sebagai sebuah solusi dalam membantu seseorang yang 
tengah mengalami sebuah permasalahan. Oleh karena itu, pendakwah atau orang yang memberi dakwah hendaknya menyampaikan dengan sebaik mungkin sehingga pesan yang disampaikan dapat dipahami pendengar. Maka, dengan mengkolaborasikan antara dakwah dengan konseling individu menjadi sebuah kajian yang menarik, sehingga dapat menjadi sebuah solusi dalam membantu mad'u yang mengalami sebuah permasalahan.

\section{DAFTAR PUSTAKA}

Amin, Samsul Munir. (2006). Konstruksi Pemikiran Dakwah Islam. Jakarta: Amzah.

Aceh, Abubakar. (1986). Potret Dakwah Muhammad SAW dan Para Sahabatnya. Solo: Ramadhani.

Arifuddin. (2015). Keluarga Dalam Pembentukan Akhlak Islamiah, Yogyakarta: Penerbit Ombak.

An-Nabiry, Fathul Bahri. (2008). Meniti Jalan Dakwah Bekal Perjuangan Para Da'I. Jakarta: Amzah.

Anshari, Endang Saifuddin. (1982). Wawasan Islam, Pokok-Pokok Pikiran tentang Islam. Bandung: Pustaka Salman.

Astuti, D. B. (2015). Layanan Konseling Individu untuk Meningkatkan Pemahaman Konsep Diri Dalam Mengarahkan Karir Siswa MAN LAB UIN Yogyakarta. Skripsi, Universitas Islam Negeri Sunan Kalijaga Yogyakarta.

Ahmad, Amrullah. (1983). Dakwah dan Perubahan Sosial. Yogyakarta: PLP2M.

Arifin. (1993). Psikologi Dakwah Suatu Pengantar. Jakarta: Bumi Aksara.
Awwaludin, Pimay. (2006). Metodologi Dakwah Kajian Teoritis dari Khazanah Al-Qur'an. Semarang: Rasail.

Baqi, Muh. Fuad Abdul. Al-Mu'jam AlMufahras li Alfazh Al-Qur'an. Cairo: Dar Al-Kutub Al-'rabiyyah.

Bambang S, Ma"arif. (2010). Komunikasi Dakwah Paradigma Untuk Aksi. Bandung: Remaja Rosdakarya.

Brammers, Lawrence. (1982). Therapeutic Psychology Fundamental of Counseling and Psychotherapy. New Jersey: Prentice Hall Inc. Englewood Cliff.

Endang Saifuddin, Anshari. (1993). Wawasan Islam Pokok-pokok Pikiran Tentang Islam dan Ummatnya. Jakarta: Raja Grafndo Persada.

Febriani, Deni. (2011). Bimbingan Konseling. Yogyakarta: Teras.

Gibson, R. L., \& Mitchel, M. H. (2011). Bimbingan dan Konseling, Alih Bahasa: Yudi Santoso. Yogyakarta: Pustaka Pelajar.

Hasjmy, A. (1984). Dustur Dakwah Menurut Al-Qur'an. Jakarta: Bulan Bintang.

Hansen, James C. (1977). Counseling Theory and Process. Boston: Allyn and Bacon Inc.

Latipun. (2001). Psikologi Konseling. Malang, Unversitas Muhammadiyah Malang.

Mahmud, Ahmad. (2006). Dakwah Islam. Bogor: Pustaka Thariqul Izzah.

Mappeare, Andi. (2002). Pengantar Konseling dan Psikoterapi. Jakarta: Raja Grafindo Persada. 
Musnamar, Thohari. (1992). Dasar-dasar Konseptual Bimbingan dan Konseling Islami. Yogyakarta: UII Prees.

Muttaqien. (1982). Peranan Dakwah Dalam Pembangunan Manusia. Surabaya: Bina Ilmu.

Mahfudz, Syaikh Ali. Hidayat AlMursyidin. Cairo : Dar Al-Kutub Al'Arabiyyah, tt.

Mulkhan, Abdul Munir. (1996). Ideologisasi Gerakan Dakwah. Yogyakarta : Sipres.

Nawawi, Imam. Riyadhush Shalihin. Surabaya : Maktabah Ahmad bin Said bin Nabhan, tt.

Nasruddin, Razak. (1973). Dinul Islam. Bandung : Al Maarif.

Panitia Sertifikasi Guru Rayon 39. (2010). Pendidikan dan Pelatihan Profesi Guru (PLPG) Sertifikasi Guru Dalam Jabatan Tahun 2010 Bimbingan Konseling. Semarang: IKIP PGRI Semarang.

Pohan, R. A., \& Ramadhani, E. (2018). Miskonsepsi Program Studi BPI/BKI Fakultas Dakwah di PTKIN. Biblio Couns: Jurnal Kajian Konseling dan Pendidikan, 1(2), 54-58.

Prayitno. (2004). Seri Pelayanan Konseling L1-L9. Padang: Universitas Negeri Padang.
Prayitno \& Amti, E. (2004). Dasar-Dasar Bimbingan Konseling. Jakarta: Rineka Cipta.

Prayitno. (1997). Pelaksanaan Bimbingan dan Konseling di Sekolah. Jakarta: Ikrar Mandiri Abadi.

Rahim, Faqih Aunur. (2001). Bimbingan dan Konseling dalam Islam. Jakarta: UII Press.

Saerozi. (2015). Pengantar Bimbingan \& Penyuluhan Islam. Semarang: Karya Abadi Jaya.

Sayid Muhammad, Nuh. (2000). Dakwah Fardiyah: Pendekatan Persoalan dalam Dakwah. Solo: Era Intermedia.

Suparta, Munzier dan Harjani Hefni. (2003). Metode Dakwah. Jakarta: Prenada Medi.

Taufq, Al-Wa'i. (1989). An-Nisaaud Daa'yaat. Kuwait: Kementrian Waqaf.

Tohirin. (2011). Bimbingan dan Konseling di Sekolah dan Madrasah. Jakarta: Rajawali Pers.

Tohirin. (2007). Bimbingan dan Konseling di Sekolah dan Madrasah. Jakarta: Raja Grafindo Persada.

Winkel, W.S. (2004). Bimbingan Konseling Pada Institusi Pendidikan. Yogyakarta: Media Abadi.

Willis, Sofyan. (2004). Konseling Individual Teori dan Praktik. Bandung: Alfabeta. 